\title{
Article \\ Exploratory and Exploitative Internationalization: Effects of Social Capital Antecedents and Fit Moderators of Innovation Consequence
}

\author{
Hang $\mathrm{Wu}^{1}$ and Yiying $\mathrm{Qu}{ }^{2, *}$ \\ 1 School of Economics, Jiaxing University, Jiaxing 314001, China; wuhang0503@163.com \\ 2 Business School, East China University of Political Science and Law, Shanghai 200042, China \\ * Correspondence: sdlzqyy@hotmail.com
}

Citation: $\mathrm{Wu}, \mathrm{H} . ; \mathrm{Qu}$, Y. Exploratory and Exploitative Internationalization: Effects of Social Capital Antecedents and Fit Moderators of Innovation Consequence. J. Theor. Appl. Electron. Commer. Res. 2021, 16, 3120-3135. https://doi.org/10.3390/jtaer16070170

Academic Editors: Krzysztof Wach and Agnieszka Głodowska

Received: 24 September 2021

Accepted: 8 November 2021

Published: 13 November 2021

Publisher's Note: MDPI stays neutral with regard to jurisdictional claims in published maps and institutional affiliations.

Copyright: () 2021 by the authors. Licensee MDPI, Basel, Switzerland. This article is an open access article distributed under the terms and conditions of the Creative Commons Attribution (CC BY) license (https:// creativecommons.org/licenses/by/ $4.0 /)$.

\begin{abstract}
Implementing international strategy is essential to enhance corporate innovation and achieve sustainable development. Existing research has theoretically illustrated the concept and importance of carrying out both exploratory and exploitative internationalization, yet our understanding of the antecedents and consequences of both activities remains unclear. Based on the data of Chinese international manufacturing firms, this paper examines the differential effects of business, government and knowledge network capital on exploratory and exploitative internationalization, and probes into how organizational, strategic, and environmental factors moderate the innovation effectiveness of exploratory and exploitative internationalization. Results indicate that business network capital has the same positive impact on exploratory and exploitative internationalization; government network capital influences the implementation of exploratory internationalization, whereas knowledge network capital influences the execution of exploitative internationalization. Furthermore, our findings reveal that, to maximize innovation performance, pursuing exploratory internationalization is more beneficial for firms with older age, firms entering into countries with low host-home country similarity, and operating in a more dynamic international environment. By contrast, pursuing exploitative internationalization is more effective for younger firms, firms entering into countries with high host-home country similarity, and in more stable international environment. Theoretical and managerial implications are discussed.
\end{abstract}

Keywords: business network capital; government network capital; knowledge network capital; exploratory internationalization; exploitative internationalization; innovation performance

\section{Introduction}

Internationalization has emerged as a critical strategy for firm's innovation and sustainability in emerging countries [1,2]. Inspired by research on organizational ambidexterity, which has been indicated in such various literatures as organizational learning and strategy [3,4], innovation [5,6], and knowledge search [7], studies in international business tend to believe that international firms need to become ambidextrous and conduct exploratory and exploitative strategies simultaneously in foreign markets [8-10]. Firms that engage in exploratory internationalization acquire new knowledge overseas to enhance existing and form new competitive advantage $[8,9,11,12]$. Firms pursuing exploitative internationalization capitalize on existing knowledge and extend existing products and services for foreign customers $[8,9,11,12]$. While the importance of pursuing both types of internationalization has often been highlighted, there are some oversights in the extant empirical research; thus, the purpose of this study is an attempt to test the antecedents and consequences of both internationalization activities, and further, to examine the differential influences of specific kinds of social capital on exploratory and exploitative internationalization, and to probe into how international firms may successfully implement exploratory and exploita- 
tive internationalization to improve innovation according to organizational, strategic and environmental conditions.

The first research gap is that there is little systematic evidence on whether and how firms adopt different social networks to carry out exploratory and exploitative internationalization. Lacking international resources and experience, the optimal choice for firms in an emerging economy to push internationalization is to rely on network resources $[13,14]$. Such networks play a valuable role in establishing channels to much-needed knowledge and financial resources, thereby increasing internationalization speed and lowering internationalization risks [15]. Although existing studies in the international business field have empirically tested the effect of ties with government officials and business managers for firms' internationalization, these researches treat internationalization as a whole strategy and obtain no consistent conclusion $[16,17]$. Therefore, it is necessary to test the differential impact of specific network resources on both types of internationalization. Except that, research in the organizational learning field can inspire us and has indicated that social capital is the key antecedent of exploration and exploitation, but these researches mainly focus on the intraindustry and extraindustry managerial ties, and do not uncover whether exploration or exploitation can be more appropriately promoted by a specific network [18,19]. This study divides social capital into more components, including business network capital, government network capital and knowledge network capital, and examines the differential influences of specific kinds of social capital on exploratory and exploitative internationalization.

The second research gap concerns the relationship between exploratory and exploitative internationalization and innovation performance. Theoretical research has divided internationalization into two types of exploration and exploitation and has emphasized the necessity of implementing both strategies [8-10]. To date, however, few, if any, empirical studies have examined the innovation consequences and moderating conditions of exploratory and exploitative internationalization. Moreover, previous research on the relationship between internationalization and innovation has tended to take internationalization as a whole unit of analysis [20] and has obtained positive [1], negative [21], nonsignificant [22], or U-shaped [23] empirical results, thereby ignoring the fact that the innovation implications of international behaviors might need to fit with contingency factors. This study probes into the effects of exploratory and exploitative internationalization on innovation performance and offers a more comprehensive understanding of how international firms may successfully implement exploratory and exploitative internationalization according to organizational, strategic and environmental conditions.

In this research, we empirically test the differential impact of business, government, and knowledge network capital on both types of internationalization. Through this richer explanation and empirical assessment, we contribute to a greater clarity and better understanding of how international firms can most effectively leverage external network to conduct specific exploratory and exploitative internationalization. Except that, we argue that the effect of internationalization on innovation can be best understood by focusing on different international behaviors and the organizational, strategic, environmental context facing an organization. We advance the growing body of literature on exploratory and exploitative internationalization by empirically testing their impact on innovation, and we answer inconsistent conclusions in the traditional international business field that the effect of internationalization on innovation performance relies on the matching between different international behaviors and contextual conditions. Figure 1 presents our theoretical model of social capital, internationalization, and innovation performance. 


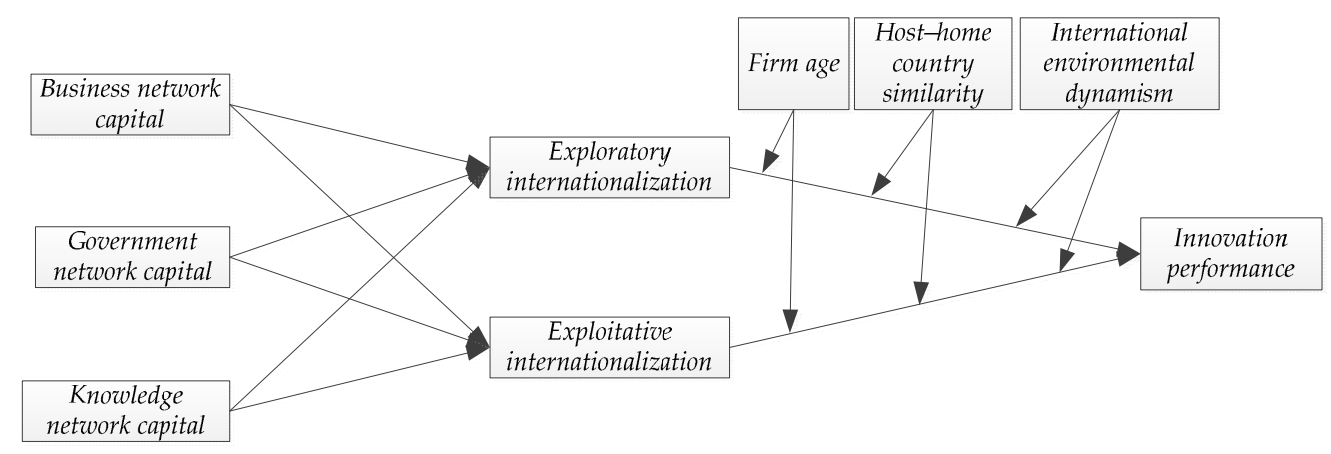

Figure 1. Theoretical model.

\section{Theory and Hypotheses}

\subsection{The Nature of Exploratory and Exploitative Internationalization}

Traditional international business literature generally views internationalization as a channel for firms to transfer and exploit firm-specific competitive advantages overseas [24]. Recent studies have recognized that firms investing in foreign countries can not only exploit their own advantages but can also explore and capture new and necessary resources to strengthen corporate long-term competitiveness $[8,9,11]$. Therefore, companies will engage in internationalization by the process of either exploration or exploitation. Building on the organizational learning perspective, March [3] argues that exploration refers to activities such as search, variation, experimentation and discovery, which can assist in gaining new knowledge and information and improving future returns, whereas exploitation involves activities such as refinement, efficiency, selection, and implementation, which helps the firm use existing knowledge and information and thus increase present returns.

Exploration and exploitation involve different aspects of organizational learning. More specifically, exploration represents learning gained through distant and shallow search for unknown knowledge along an entirely different trajectory, while exploitation represents learning gained through local search and repeated use for known knowledge along the same trajectory $[4,7]$. In view of this, explorative internationalization can be defined as a kind of learning activity through a broad search for new knowledge and complementary assets in the international markets, which are far beyond the current experience of the firm. By contrast, exploitative internationalization refers to learning activity through local and deep search for repeated usage of the same knowledge in the international markets, which relates to the firm's previous experience and knowledge domain.

\subsection{Social Capital Antecedents of Exploratory and Exploitative Internationalization}

Social capital theory postulates that firms do not exist in the society alone but instead forms social networks with outsider parties due to various reasons [25]. Firms can gain knowledge and resources by tapping into the networking relationships to fulfill personal goals and action [15]. Because of the actors' difference in controlling resources, different types of social networking relationships may give rise to differentiated network resources. In this study, we mainly focus on three kinds of social capital: business network capital, government network capital, and knowledge network capital. Business network capital refers to personal and social relationships with suppliers, customers, and competitors [26,27]. Government network capital is developed through a variety of government political and bureaucratic institutions [26,27]. Knowledge network capital is formed through firm's frequent interactions with universities, consulting company and scientific research institutions $[27,28]$. The social capital formed through external networks plays a vital role in the transmission of information, resources, and opportunities that could be used during a firm's internationalization. 
2.2.1. Relative Influence of Business Network Capital on Exploratory and Exploitative Internationalization

Existing research has suggested that business network plays an important role in a firm's internationalization, through which many domestic firms learn foreign technological and marketing knowledge beneficial for internationalization $[16,17]$. However, we highlight that business network capital has a stronger positive impact on exploitative internationalization than exploratory internationalization. Exploratory internationalization is to seek and acquire new knowledge overseas, which proposes a higher request to firms resource reserve and risk bearing capacity. In contrast, exploitative internationalization is about leveraging existing knowledge to capitalize on market opportunities-the key success point of which is to establish a stable production system and fully understand foreign customer preference, as well as a political and legal environment $[4,29]$. Good networking relationships with suppliers provide international firms with premium quality raw materials and timely delivery service, good ties with customer help international firms improve product attractiveness and understand consumption tendency, and good relationships with competitors can spur inter-firm cooperation and further push product upgrading [27]. In view of this, we argue that business network capital must be more prone to helping firms exploit in the international markets. Therefore, we propose that:

Hypothesis 1 (H1). Compared to exploratory internationalization, business network capital is more strongly positively related to exploitative internationalization.

2.2.2. Relative Influence of Government Network Capital on Exploratory and Exploitative Internationalization

Ties with government officials represent a unique type of managerial resource [30]. After decades of structural reform, government still controls various resources and owns the right to allocate resources, which leads firms to tend to pay disproportionately greater attention in establishing relationships with government officials [27]. Although contact with government can help firms obtain information and funding that is beneficial for entering into international markets, we argue that government network capital is more profitable for exploratory internationalization than exploitative internationalization. Compared to exploitative internationalization, which requires the firm to own certain foreign marketing knowledge and technological capability, exploratory internationalization is a huge-input and high-risk activity with uncertain short-term income, imposing heavy burdens on a firm's financial condition [4,29]. It is noteworthy that government can provide opportunities for firms to understand foreign culture, customer demand and commercial institutions, such as participating in an international fair, but marketing and technological knowledge learned from this channel may be superficial and cannot directly be used in a firm's production. Instead, firms are more inclined to treat government institutions as a source of financing and cost reduction through such programs as soft loan support, export subsidies, tax reduction and exemption, which can greatly increase international firms' risk-taking capability and finally promote exploratory internationalization $[17,31]$. Therefore, we propose that:

Hypothesis 2 (H2). Compared to exploitative internationalization, government network capital is more strongly positively related to exploratory internationalization.

2.2.3. Relative Influence of Knowledge Network Capital on Exploratory and Exploitative Internationalization

Ties with such knowledgeable entities as universities, consulting companies and scientific research institutions have not received enough attention in international business research field. Knowledge networks can provide international firms with plenty of scientific and technological knowledge [32]. Although the prerequisite of both exploring and exploiting overseas is to own certain knowledge, we still hold that a relationship with knowledge networks is more beneficial for exploitative internationalization, rather than ex- 
ploratory internationalization. As we have mentioned above, the biggest obstacle for firms to implement exploratory internationalization is about risk-bearing capacity stemming from resource constraints, and the major barrier to exploit competitive advantage overseas is to produce competitive products that meet the needs of foreign markets [4,29]. Through entering into knowledge networks, international firms can take over intellectual resources by cooperating with universities and research institutions to conquer technical problems, and finally successfully launch new products to foreign customers [32], which directly determine the success or failure of exploitative internationalization. Zhang and Li [28] found that such service intermediaries as consulting companies can not only help firms solve technical problems straightforward, but can also provide other optional connections to firms when they cannot effectively solve the problem. Therefore, we propose that:

Hypothesis 3 (H3). Compared to exploratory internationalization, knowledge network capital is more strongly positively related to exploitative internationalization.

\subsection{Impacts of Exploratory and Exploitative Internationalization on Innovation Performance}

2.3.1. Exploratory Internationalization and Innovation Performance

Exploratory internationalization arises out of a necessity for firms to learn and obtain novel technological and marketing knowledge and information in overseas markets. Exploratory internationalization can positively influence innovation in two aspects $[7,19,33]$. Exploring overseas can enrich firms' knowledge pool by adding new variants of technological and market information. The rise in the amount and novelty of knowledge repository may increase international firms' innovative problem-solving capability. $\mathrm{Wu}$ and Chen [9] point out that exploratory internationalization can help international firms avoid the competence trap and avoid short-sightedness through continuously bringing a large amount of differentiated information that significantly enhances the ability of firms to launch new products and improve innovation process. Conversely, exploring overseas can provide firms with new insights and innovative ideas that help firms differentiate from other competitors. Mihalache, Jansen, Van Den Bosch, and Volberda [34] argue that novel knowledge sourced overseas can help firms increase useful knowledge recombination, update the thinking mode, and win out over competitors. Therefore, we propose that:

Hypothesis 4 (H4). Exploratory internationalization is positively related to innovation performance.

\subsubsection{Exploitative Internationalization and Innovation Performance}

The aim of conducting exploitative activities overseas for international firms is to fully use their competitive advantages in foreign markets. Exploitative internationalization can positively influence innovation in three ways $[7,19,33]$. First, repeatedly using the firm's technological and marketing knowledge elements can improve innovation efficiency via finding the most cost-effective ways to solve product development problems. Through the reuse of existing knowledge, managers can better understand the distribution and functionality of internal knowledge and thus be able to integrate existing knowledge to discover and integrate new innovation opportunities [9]. Second, increased familiarities with an existing operational domain reduce errors in problem solving and avoid mistakes in product development process. Lastly, exploitative internationalization provides firms with greater opportunities to find new ways for the recombination of existing knowledge, which helps gain new insight into the innovation process. Wu and $\mathrm{Qu}$ [22] argue that a thorough understanding of the foreign context developed through extensive exploitative internationalization can help EM MNEs refine any technologies discovered and adapt them to address foreign market needs, leading to successful new products that appeal to foreign customers. Therefore, we propose that:

Hypothesis 5 (H5). Exploitative internationalization is positively related to innovation performance. 


\subsection{Organizational, Strategic and Environmental Contingencies of Exploratory and Exploitative Internationalization}

We argue that a firm's innovation performance can be both positively affected by the choices of exploration and exploitation strategies in its internationalization, but more importantly, the innovative effects of exploratory and exploitative internationalization are subject to a joint consideration of their fit with organizational, strategic, and environmental factors. Contingency scholars have argued that the best way to organize depends on the nature of the environment to which the organization must relate [35], and a decision maker needs to work hard to achieve the alignment between organizational goals and the internal and external environmental conditions [36]. Therefore, we can imagine that the innovation performance of international firms depends on the congruence between the choices of exploratory and exploitative internationalization and the environment, strategy, and firm characteristics.

2.4.1. Organizational Fit: Exploratory Internationalization, Exploitative Internationalization and Firm Age

As an important indicator for a firm's accumulative resource base, firm age plays a critical role in a firms' strategic decisions and performance [37]. We expect that innovation performance is affected by a fit between its international strategies (firms' choice between exploratory and exploitative internationalization) and firm age. In general, younger firms face a liability of newness and smallness and have limited internal resources and capabilities and external networks as opposed to more mature firms [33]. Although exploratory internationalization provides younger firms with considerable novel knowledge and information, it is a real high-risk challenge for them to devote or borrow enough resources to integrate the knowledge learned overseas. Therefore, the innovation effect of exploratory internationalization may be limited for younger firms, and younger firms tend to choose and benefit more from exploitative internationalization, which enables them to make more efficient use of their existing resources and capabilities.

When firms age, successful exploitative practices tend to be retained, reinforced, and developed into organizational memories and routines [38], which make firms fall into organizational simplicity, competency traps and core-rigidity $[39,40]$. Then, it is a wise choice for older firms to choose and implement exploratory internationalization, which provides them with significant learning opportunities to renew obsolete resources and capabilities. In contrast, exploiting competitive advantages in the international markets cannot provide much new knowledge and cutting-edge thinking for an older firm's update. Therefore, we propose that:

Hypothesis 6 (H6a). Older firms will benefit higher innovation performance from exploratory internationalization.

Hypothesis 6 (H6b). Younger firms will benefit higher innovation performance from exploitative internationalization.

2.4.2. Strategic Fit: Exploratory Internationalization, Exploitative Internationalization and Host-Home Country Similarity

The strategic fit between international strategies and market selection decisions is critical to a firms' innovation performance because this alignment enables firms to take full advantage of their respective strategies [41]. Entering into foreign countries with low hosthome country similarity on a social culture, political institution, and economic development level provides ample learning opportunities for exploration-oriented firms [42]. Firms can leverage new technological and marketing knowledge learned overseas to create new products. However, if firms implement exploitative strategy in dissimilar countries, they will soon find that their products are uncompetitive and unsuitable for foreign customers. In other words, countries with a low level of host-home country similarity may work 
to prohibit exploitation-oriented firms from leveraging their knowledge and skills to enhance innovation.

In contrast, when firms select to enter into foreign countries with high host-home country similarity in terms of social and business culture, political institution and economic development level, it means that they can repeatedly capitalize on current knowledge/skills and existing products/services with minimal change [43], and can finally obtain increased innovation efficiency and reduced innovation errors and mistakes [7]. Otherwise, we expect firms that implementing exploratory internationalization strategy in similar countries will acquire non-differential technological and marketing information that may not be useful for innovation. In other words, a high level of host-home country similarity may hinder exploration-oriented firms from seeking novel knowledge to enhance innovation. Therefore, we propose that:

Hypothesis 7 (H7a). When firms enter into foreign countries with low host-home country similarity, firms will benefit higher innovation performance from exploratory internationalization.

Hypothesis $7 \mathbf{~ ( H 7 b ) . ~ W h e n ~ f i r m s ~ e n t e r ~ i n t o ~ f o r e i g n ~ c o u n t r i e s ~ w i t h ~ h i g h ~ h o s t - h o m e ~ c o u n t r y ~}$ similarity, firms will benefit higher innovation performance from exploitative internationalization.

2.4.3. Environmental Fit: Exploratory Internationalization, Exploitative Internationalization and International Environmental Dynamism

International environmental dynamism refers to the rate of change and the degree of instability of the environment [44], such as technology, customer preferences, competitor, product demand or supply of materials [4]. High dynamic international environments are associated with more novel technological and marketing opportunities, and high-risk of technological obsolescence [5,33]. To minimize this threat of obsolescence, it is prudent for firms to explore in dynamic international environment with booming innovation opportunity, which helps international firms create new products and services. In this environment, we expect that firms pursuing exploitative internationalization are likely to obtain decreasing innovation performance because they become consistently better at making slight modification in existing products, which cannot meet the dynamic demand of emerging markets.

In contrast, slow increase in demand, low turnover of rivals, and greater technology stability characterize low dynamic international environments [5,33]. Then, managers face low pressure to have to implement high-risk and enormous resource-committing exploratory internationalization, and are inclined to turn to reuse existing resources and capabilities to reap the predictable benefits of exploitative internationalization. Under the circumstances, we expect that firms pursuing exploratory internationalization will devote a large sum of resources in exploration and produce too premium and advancing products and services that do not meet the existing market's demand, but which finally hurt firm's innovation. Thus, firms in a low dynamic international environment will reap more benefits by exploitative internationalization as opposed to exploratory internationalization. Therefore, we propose that:

Hypothesis 8 (H8a). In a high dynamic international environment, firms will benefit higher innovation performance from exploratory internationalization.

Hypothesis $\mathbf{8} \mathbf{( H 8 b )}$. In a low dynamic international environment, firms will benefit higher innovation performance from exploitative internationalization.

\section{Methodology}

\subsection{Sample and Data Collection}

Our study's sampling frame was international manufacturing enterprises located in the industrial parks in Zhejiang province in China. Existing research has proven that the Chinese government strongly encourages the internationalization of enterprises in the past 
two decades, and Zhejiang is one of the most active international regions in China because of its highly developed private economy and early internationalization pace [1,45]. Thus, the Zhejiang context offers a rich setting in which to test our hypotheses. We drew on a random sample of 700 new ventures from a list of 2000 firms.

We selected the top managers responsible for international operations and innovation management as the key informant. After several rounds of phone, fax, and personal follow-ups, 227 valid questionnaires (32.4 percent) were returned after deleting replies with missing observations. Of the responding multinational enterprises, $30.40 \%$ were in the electronic information industry, $19.38 \%$ were in special equipment manufacturing, $13.22 \%$ were in transportation equipment manufacturing, $12.78 \%$ were in ordinary machinery manufacturing, $9.25 \%$ were in the metal products industry, and $14.97 \%$ were classified as other (e.g., textiles and clothing). As for the common method bias, Harmon's one-factor test showed that no single factor explained a majority of the variance, demonstrating that common method bias was not a serious concern in this study.

\subsection{Measures, Reliability and Validity}

\subsubsection{Dependent Variable}

Following the approach of Chen, Chen and Vanhaverbeke [46], $\mathrm{Wu}$, Chen and Jiao [1] and $\mathrm{Wu}, \mathrm{Chen}$ and Liu [47], we used six items to measure innovation performance, which reflected the performance conditions in terms of new products development and sales comparing to their major competitors in the same industry.

\subsubsection{Independent Variables}

The measurement scales of exploratory and exploitative internationalization were developed based on the understanding of Makino, Lau and Yeh [8] and Hsu, Lien and Chen [11], with the measurement items adapted from Cui, Meyer and Hu [41] on strategic asset seeking, market seeking and efficiency seeking, adjusted from Luo [45] on capability building and capability exploitation.

Adapted from Park and Luo [26] and Peng and Luo [27], we used four items to measure business network capital by asking the respondents to assess the degree to which their firms established close cooperation connections with such business partners as customers, suppliers, competitors. We measured government network capital with four items adjusted from Peng and Luo [27] and Zhang, Zhang and Bell [32]. On the basis of work by Zhang and Li [28], and Guan and Liu [30], knowledge network capital was quantified by combining data on three sources of knowledge or information used in internationalization, including (1) universities, (2) scientific research institutions, and (3) technological intermediaries.

\subsubsection{Moderating Variables}

Firm age was operationalized as the number of years since the firm was founded. Based on the work of Jaworski and Kohli [48] and Jansen, Van Den Bosch and Volberda [5], a three-item scale was used for international environmental dynamism tapping into the rate of change and the instability of the international environment. Following Cui, Meyer and $\mathrm{Hu}$ [41], host-home country similarity was measured with three items that reflected the similarity between the targeted country and the home country in the following dimensions: (1) business culture, (2) political and legal system, and (3) economic development.

\subsubsection{Controls}

Four variables that may affect a firm's internationalization were controlled. First, firm size was operationalized as the natural log value of the total employees. Second, R\&D intensity was measured as R\&D expenditures as a percentage of sales because firms with higher levels of R\&D investment tended to have better innovation performance. Third, international experience was measured by the number of years that a firm had engaged in international business [49]. Finally, we used five dummy variables, industry dummy 1 (electronic information), industry dummy 2 (special equipment manufacturing), industry 
dummy 3 (transportation equipment manufacturing), industry dummy 4 (ordinary machinery manufacturing), and industry dummy 5 (metal product) to control for industry effects.

\subsubsection{Reliability and Validity of the Constructs}

The alpha reliabilities of our constructs were greater than the recommended 0.70 (as seen in Table 1), ranging from 0.900 to 0.985 , which shows good reliability. An integrated eight-factor confirmatory factor analysis (CFA) showed that the model fit the data well $\left(\chi^{2}=807.072, p=0.000 ; \chi^{2} / \mathrm{df}=1.728, \mathrm{NNFI}=0.954, \mathrm{CFI}=0.959, \mathrm{IFI}=0.959\right.$, RMSEA $=0.057)$. Item loadings were as proposed and significant $(p<0.01)$, as shown in Table 1 . To test the discriminant validity, we also calculated the average variance extracted (AVE) for each construct and found that the AVE by the measure of each factor was larger than the squared correlation of that factor's measure, with all measures of other factors in the model, strongly supporting the discriminant validity.

Table 1. Construct measurement and confirmatory factor analysis results.

\begin{tabular}{|c|c|}
\hline Constructs/Measurement Items & Standardized Loadings \\
\hline \multicolumn{2}{|l|}{ Business network capital (Cronbach $\alpha=0.924, A V E=0.752$ ) } \\
\hline 1. Establish close cooperation connections with customers & 0.881 \\
\hline 2. Keep tight cooperation relationships with suppliers & 0.871 \\
\hline 3. Build friendly cooperation relationships with competitors & 0.884 \\
\hline 4. Spend much effort in cultivating good relations with business partners & 0.832 \\
\hline \multicolumn{2}{|l|}{ Government network capital (Cronbach $\alpha=0.933, A V E=0.779$ ) } \\
\hline 1. Devote much energy to build close ties with officials of government and its agencies & 0.904 \\
\hline 2. Establish friendly relationships with officials in industrial bureaus & 0.856 \\
\hline $\begin{array}{l}\text { 3. Build friendly relations with regulatory and supporting organizations such as state banks, tax } \\
\text { bureaus, commercial administration bureaus and other governmental agencies }\end{array}$ & 0.873 \\
\hline 4. Receive favorable treatment from government and its agencies & 0.896 \\
\hline \multicolumn{2}{|l|}{ Knowledge network capital (Cronbach $\alpha=0.909, A V E=0.770$ ) } \\
\hline 1. Keep good cooperation relationship with universities & 0.872 \\
\hline 2. Keep good cooperation relationship with scientific research institutions & 0.877 \\
\hline 3. Keep good cooperation relationship with technological intermediaries & 0.883 \\
\hline \multicolumn{2}{|l|}{ Exploratory internationalization (Cronbach $\alpha=0.963, A V E=0.841$ ) } \\
\hline 1. Recruit high-level R\&D and management talent in foreign markets & 0.895 \\
\hline 2. Seek technological and marketing resources overseas for firm's development & 0.899 \\
\hline 3. Acquire the managerial know-how of foreign peers for further improvement & 0.907 \\
\hline 4. Take advantage of foreign advanced R\&D infrastructure & 0.894 \\
\hline 5. Obtain global business information and technology spillover & 0.987 \\
\hline \multicolumn{2}{|l|}{ Exploitative internationalization (Cronbach $\alpha=0.921, A V E=0.702$ ) } \\
\hline 1. Leverage technological advantages in foreign markets & 0.847 \\
\hline 2. Enter into foreign markets to expand the market space & 0.833 \\
\hline 3. Intend to lower transportation cost by producing abroad & 0.854 \\
\hline 4. Utilize cheap labor and raw material in foreign markets & 0.839 \\
\hline 5. Expand into foreign markets to benefit from investment incentives & 0.816 \\
\hline \multicolumn{2}{|l|}{ Host-home country similarity (Cronbach $\alpha=0.900, A V E=0.760)$} \\
\hline 1. The foreign country we enter has similar business cultures as home country & 0.874 \\
\hline 2. The foreign country we enter has similar political and legal system as home country & 0.879 \\
\hline 3. The foreign country we enter is as economically developed as home country & 0.863 \\
\hline \multicolumn{2}{|l|}{ International environmental dynamism (Cronbach $\alpha=0.912, A V E=0.777)$} \\
\hline 1. Technologies change rapidly in foreign markets & 0.886 \\
\hline 2. Foreign Customers regularly ask for new products and services & 0.890 \\
\hline 3. Foreign competitors regularly launch new products and services & 0.869 \\
\hline \multicolumn{2}{|l|}{ Innovation performance (Cronbach $\alpha=0.985, A V E=0.917)$} \\
\hline 1.The number of new products & 0.955 \\
\hline 2.The ratio of new products sales to total sales & 0.959 \\
\hline 3.The speed of new product development & 0.953 \\
\hline 4.The success ratio & 0.954 \\
\hline 5.The number of patent applications & 0.973 \\
\hline 6.The novelty of new product & 0.952 \\
\hline
\end{tabular}

Notes: All standardized coefficient loadings are significant at $p<0.001 ; \mathrm{AVE}$, average variance extracted for each multi-item construct in the research model. 


\section{Analysis and Results}

We conducted a structural equation modeling with chi-square comparison to test hypotheses 1 to 3 , and we used a hierarchical moderated regression analyses for exploratory internationalization, exploitative internationalization and innovation performance to test hypotheses 4 to 8 . To reduce multicollinearity, we mean-centered the relevant variables before creating the interaction terms. Calculation of variance inflation factors (VIF) showed that the maximum value of VIF in the regression models was below three, indicating that multicollinearity was not a serious problem. Table 2 presents descriptive statistics and correlations for the study variables.

Table 2. Means, standard deviations, and correlations.

\begin{tabular}{|c|c|c|c|c|c|c|c|c|c|c|c|c|c|c|}
\hline & Mean & S.D. & 1 & 2 & 3 & 4 & 5 & 6 & 7 & 8 & 9 & 10 & 11 & 12 \\
\hline 1. Firm size & 7.536 & 10.388 & 1 & & & & & & & & & & & \\
\hline $\begin{array}{l}\text { 2. Firm age } \\
\text { 3. R\&D intensity }\end{array}$ & 15.80 & 80.246 & $0.263^{* *}$ & $\begin{array}{c}1 \\
0.052\end{array}$ & 1 & & & & & & & & & \\
\hline 4. International experience & 6.970 & 3.730 & 0.021 & -0.036 & $0.457^{* *}$ & 1 & & & & & & & & \\
\hline 5. Exploratory internationalization & 3.957 & 10.349 & $0.198^{* *}$ & -0.001 & $0.220 * *$ & $0.172 * *$ & 1 & & & & & & & \\
\hline 6. Exploitative internationalization & 4.591 & 10.066 & 0.143 * & 0.041 & $0.237^{* *}$ & $0.176^{* *}$ & $0.187 * *$ & 1 & & & & & & \\
\hline 7. Business network capital & 40.293 & 10.116 & 0.127 & 0.009 & 0.201 ** & 0.120 & $0.480^{* *}$ & $0.584 * *$ & 1 & & & & & \\
\hline 8. Government network capital & 40.275 & 10.136 & $0.230^{* *}$ & 0.048 & $0.147 *$ & 0.036 & 0.517 ** & $0.498^{* *}$ & $0.696^{* *}$ & 1 & & & & \\
\hline 9. Knowledge network capital & 40.136 & 10.219 & 0.064 & 0.006 & $0.211 * *$ & $0.148^{*}$ & $0.365^{* *}$ & $0.615^{* *}$ & $0.551^{* *}$ & $0.499 * *$ & 1 & & & \\
\hline 10. Host-home country similarity & 4.772 & 10.182 & -0.076 & $-0.206^{* *}$ & $-0.220^{* *}$ & -0.046 & -0.128 & -0.110 & $-0.147^{*}$ & -0.098 & -0.110 & 1 & & \\
\hline 11. International environmental dynamism & 40.267 & 10.246 & $-0.145^{*}$ & $0.213^{* *}$ & -0.007 & -0.018 & -0.097 & $0.174 * *$ & $0.142 *$ & 0.015 & $0.142 *$ & $-0.274^{* *}$ & 1 & \\
\hline 12.Innovation performance & 3.965 & 1.671 & $00.203^{* *}$ & 0.065 & $0.344^{* *}$ & $0.212^{* *}$ & 0.420 ** & 0.306 ** & 0.251 ** & 0.217 ** & $0.246^{* *}$ & $-0.322 * *$ & 0.074 & 1 \\
\hline
\end{tabular}

Note: ${ }^{* *} p<0.01 ; * p<0.05$.

\subsection{Antecedents of Exploratory and Exploitative Internationalization}

Following the approach suggested by Hoskisson, Hitt, Johnson and Grossman [50], we used a two-stage procedure to test the relative impact of social capital on exploratory and exploitative internationalization. The first stage involved obtaining the estimation of the theoretical measurement model, as shown in Figure 2, which provides path coefficients for the next hypothesis tests. We examined the structural relationships of the model using AMOS software. The results show that the structural model fit the data well $\left(\chi^{2}=352.853\right.$, $p<0.001, \chi^{2} / \mathrm{df}=1.960, \mathrm{NFI}=0.928, \mathrm{NNFI}=0.957, \mathrm{CFI}=0.963, \mathrm{IFI}=0.963, \mathrm{RMSEA}=0.065$ ). The path coefficients are shown in Figure 2. The second stage was to compare the theoretical model with the constrained measurement model. If the chi-square statistic increases significantly then we know the constraint is invalid and that the path coefficients are significantly different, which provides support for our hypotheses.

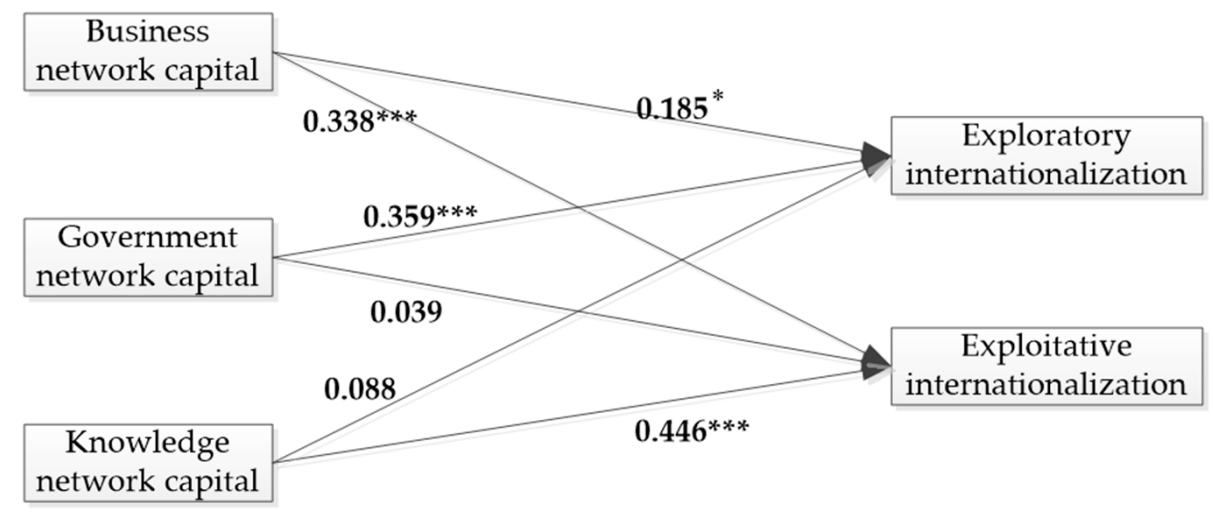

Figure 2. Path coefficients of theoretical model. Note: ${ }^{*} p<0.1,{ }^{* * *} p<0.001$, parameters are standardized parameter estimates.

Table 3 presents the results of the hypothesis tests. The first row presents the model statistics for the theoretical model. This model is used to compare successive models in which constraints are imposed. The Omnibus test constrains the three path coefficient pairs to be equal in one global test. The significant increase in chi-square $\left(\Delta \chi^{2}=13.118\right.$, $\Delta \mathrm{df}=3, p<0.01$ ) indicates that some of the path coefficients are significantly different. The subsequent three rows present the test of each of the three hypotheses. 
Table 3. Test for differences in parameter estimates.

\begin{tabular}{|c|c|c|c|c|c|c|c|c|}
\hline Model & Paramet & Estimates & $x^{2}$ & $\Delta x^{2}$ & df & $\triangle \mathbf{d f}$ & $p$ & Result \\
\hline Theoretical model & & & 352.853 & & 180 & & & \\
\hline Omnibus test & & & 365.971 & 13.118 & 183 & 3 & $<0.01$ & \\
\hline Partial restricted model $1\left(\mathrm{H}_{6}\right)$ & 0.190 * & $0.344^{* * *}$ & 353.229 & 0.376 & 181 & 1 & $>0.1$ & No support \\
\hline Partial restricted model $2\left(\mathrm{H}_{7}\right)$ & $0.336^{* * *}$ & 0.019 & 360.229 & 7.376 & 181 & 1 & $<0.01$ & Support \\
\hline Partial restricted model $3\left(\mathrm{H}_{8}\right)$ & 0.093 & $0.453^{* * *}$ & 360.025 & 7.172 & 181 & 1 & $<0.01$ & Support \\
\hline
\end{tabular}

Note: ${ }^{*} p<0.1,{ }^{* * *} p<0.001$. The theoretical model is an unrestricted model. The omnibus test constrains the parameter estimates for each hypothesis to equal each other in one global test.

The results in Figure 2 show that business network capital is positively and significantly related to exploratory internationalization $(\beta=0.185, p<0.1)$ and exploitative internationalization $(\beta=0.338, p<0.001)$. The comparative analysis results in Table 3 testing Hypothesis 1 confirm that the chi-square change $\left(\Delta \chi^{2}=0.376, \Delta \mathrm{df}=1, p>0.1\right)$ is not statistically significant indicating the path coefficients are not different. Therefore, hypothesis 1 is not supported.

The results in Figure 2 show that government network capital is positively and significantly related to exploratory internationalization $(\beta=0.359, p<0.001)$, while the impact of government network capital on exploitative internationalization is positive but not significant $(\beta=0.039, p>0.1)$. The comparative analysis results in Table 3 testing Hypothesis 2 confirm that the chi-square change $\left(\Delta \chi^{2}=7.376, \Delta \mathrm{df}=1, p<0.01\right)$ is significant, indicating that government network capital is more positively related to exploratory internationalization than exploitative internationalization. Therefore, Hypothesis 2 is supported.

Except that, the results in Figure 2 also show that the relationship between knowledge network capital and exploratory internationalization is positive, but not significant $(\beta=0.088, p>0.1)$, while the relationship between knowledge network capital and exploitative internationalization is significantly positive $(\beta=0.446, p<0.001)$. The significant increase in chi-square $\left(\Delta \chi^{2}=7.172, \Delta \mathrm{df}=1, p<0.01\right)$ of comparative analysis results in Table 3 testing Hypothesis 3 indicates that the path coefficients are statistically different. Therefore, Hypothesis 3 is supported.

\subsection{Effects of Exploratory and Exploitative Internationalization on Innovation Performance}

The results of moderated regression analysis are shown in the Table 4. As the baseline model, Model 1 only includes control variables and moderating variables. Model 2 introduces the explanatory variables of exploratory internationalization and exploitative internationalization. Model 3 contains the interaction terms of exploratory internationalization and firm age, exploitative internationalization and firm age. Model 4 contains the interaction terms of exploratory internationalization and host-home country similarity, exploitative internationalization and host-home country similarity. Model 5 contains the interaction terms of exploratory internationalization and international environmental dynamism, exploitative internationalization and international environmental dynamism.

Model 2 shows that the coefficients for exploratory internationalization $(\beta=0.285$, $p<0.001)$ and exploitative internationalization $(\beta=0.142, p<0.05)$ are positive and significant, Hypotheses 4 and 5 are supported. Model 3 shows that the interaction between exploratory internationalization and firm age is positive and significant $(\beta=0.191, p<0.01)$; Hypothesis $6 \mathrm{a}$ is supported. Model 3 also shows that the interaction between exploitative internationalization and firm age is negative and significant $(\beta=-0.172, p<0.01)$; Hypothesis $6 \mathrm{~b}$ is supported. Model 4 indicates that the coefficient for the interaction between exploratory internationalization and host-home country similarity is negative and significant ( $\beta=-0.125, p<0.05)$; Hypothesis $7 \mathrm{a}$ is supported. Model 4 also indicates that the coefficient for the interaction between exploitative internationalization and hosthome country similarity is positive and significant $(\beta=0.279, p<0.001)$; Hypothesis $7 \mathrm{~b}$ is supported. In model 5 , the significantly positive coefficient for the interaction between exploratory internationalization and international environmental dynamism $(\beta=0.288$, 
$p<0.001)$ reveals that Hypothesis $8 \mathrm{a}$ is supported. The significant and negative coefficient for the interaction between exploitative internationalization and international environmental dynamism $(\beta=-0.201, p<0.001)$ reveals that Hypothesis $8 \mathrm{~b}$ is supported.

Table 4. Results of moderated regression analysis.

\begin{tabular}{|c|c|c|c|c|c|}
\hline & Model 1 & Model 2 & Model 3 & Model 4 & Model 5 \\
\hline Industry dummy 1 (electronic information) & -0.192 & -0.160 & -0.154 & -0.165 & $-0.181 *$ \\
\hline Industry dummy 2 (special equipment manufacturing) & 0.016 & -0.019 & -0.031 & -0.021 & -0.074 \\
\hline Industry dummy 3 (transportation equipment manufacturing) & -0.085 & -0.102 & -0.119 & -0.094 & $-0.133 *$ \\
\hline Industry dummy 4 (ordinary machinery manufacturing) & 0.025 & 0.001 & 0.009 & -0.028 & -0.014 \\
\hline Industry dummy 5 (metal product) & 0.004 & -0.017 & -0.027 & -0.010 & -0.031 \\
\hline Firm size & $0.257 * * *$ & $0.162 *$ & $0.160 *$ & 0.144 * & $0.154 * *$ \\
\hline R\&D intensity & $0.237^{* *}$ & $0.172 *$ & 0.165 * & $0.163 *$ & 0.099 \\
\hline International experience & 0.084 & 0.049 & 0.063 & 0.062 & 0.088 \\
\hline Firm age & -0.053 & -0.031 & -0.035 & -0.007 & -0.036 \\
\hline Host-home country similarity & $-0.301^{* * *}$ & $-0.256^{* * *}$ & $-0.257^{* * *}$ & $-0.208^{* *}$ & $-0.201^{* *}$ \\
\hline International environmental dynamism & 0.062 & 0.060 & 0.046 & 0.008 & 0.074 \\
\hline Exploratory internationalization & & $0.285^{* * *}$ & $0.286^{* * *}$ & $0.340 * * *$ & $0.283 * * *$ \\
\hline Exploitative internationalization & & $0.142 *$ & 0.136 * & $0.141 *$ & $0.149 * *$ \\
\hline Exploratory internationalization * Firm age & & & $0.191 * *$ & & \\
\hline Exploitative internationalization * Firm age & & & $-0.172 * *$ & & \\
\hline $\begin{array}{l}\text { Exploratory internationalization * Host-home country } \\
\text { similarity }\end{array}$ & & & & $-0.125 *$ & \\
\hline $\begin{array}{l}\text { Exploitative internationalization * Host-home country } \\
\text { similarity }\end{array}$ & & & & $0.279 * * *$ & \\
\hline $\begin{array}{l}\text { Exploratory internationalization * International environmental } \\
\text { dynamism }\end{array}$ & & & & & $0.288 * * *$ \\
\hline $\begin{array}{l}\text { Exploitative internationalization * International environmental } \\
\text { dynamism }\end{array}$ & & & & & $-0.201^{* * *}$ \\
\hline $\mathrm{R}^{2}$ & 0.261 & 0.356 & 0.405 & 0.417 & 0.458 \\
\hline $\mathrm{F}$ & $6.912 * * *$ & $9.071 * * *$ & $9.557 * * *$ & $10.055^{* * *}$ & $11.906 * * *$ \\
\hline Max VIF & 2.551 & 2.562 & 2.575 & 2.568 & 2.588 \\
\hline
\end{tabular}

Note: Standardized regression coefficients are reported. ${ }^{*} p<0.05,{ }^{* *} p<0.01,{ }^{* * *} p<0.001$.

\section{Discussion}

\subsection{Main Findings}

The objective of this study was to explore the social capital antecedents of exploratory and exploitative internationalization, and to gain a greater understanding of the innovation implication and context conditions of both kinds of internationalization. Our findings suggest that business network capital has a positive influence on exploratory internationalization - the same as exploitative internationalization — which do not provide support for business network capital as predicted. A possible explanation for the phenomenon could be that business network can not only help international firms establish stable production systems and optimize technological innovation systems beneficial for the exploitation of ownership advantages overseas, but can also provide financing supports for the exploration in foreign markets. With regard to government and knowledge network capital, we find that government and knowledge network capital have unique influences on exploratory and exploitative internationalization. Specifically, the findings indicate that the implementation of exploitative internationalization is primarily derived from knowledge network capital, whereas exploratory internationalization primarily comes from government network capital.

In addition to enhancing our understanding of the antecedents of exploratory and exploitative internationalization, the results of this study also find that the relationship between exploratory and exploitative internationalization and innovation performance both are positive, empirically confirming whether exploring or exploiting overseas can be used to learn helpful knowledge spent on innovation. The positive innovation implication of exploratory internationalization is consistent with prior research on exploration and product innovation $[7,18,19]$, indicating that there do not exist overexploration phenomena in Chinese international firms. Conversely, the positive argument of exploitative internationalization is contrary to Katila and Ahuja's [7] inverted U-shaped result, testifying that 
Chinese firm exploitation of ownership advantage is still at the initial beginning stage and that overexploitation has not yet appeared.

The results of our analyses also reveal the importance of fit between different international behaviors and internal and external context factors in promoting firm innovation performance. Specifically, the results show that firms whose international behaviors fit such organizational characteristics as their age will experience higher innovation performance, meaning that younger firms benefit more from exploitative internationalization, while older firms benefit more from exploratory internationalization. Similarly, we found that hosthome country similarity further strengthens the link between international behaviors and innovation performance, demonstrating that the matching between international strategies and market selection decisions (e.g., exploratory internationalization and low host-home country similarity, exploitative internationalization and high host-home country similarity) leads to higher innovation performance. This finding is consistent with studies in strategic fit literature that emphasizes that enterprises' international performance is influenced by the fit or congruency between their chosen strategies and host-home country similarity [41]. Furthermore, our findings also show that the implementation of exploratory and exploitative internationalization needs to fit with the external environment. Firms operating in high dynamic foreign markets will benefit higher innovation performance from exploratory internationalization, while firms operating in a stable international environment will benefit higher innovation performance from exploitative internationalization.

\subsection{Theoretical and Managerial Implications}

The present study makes several important contributions to the literature. First, our findings can contribute to literature about the relationship between social capital and internationalization and corresponding research in the organizational learning field. Because of resources and experience constraint, it has been widely accepted that firms in emerging countries need to rely on external network to internationalize. However, empirical studies have only investigated the influence of such social capital as business and government network capital on internationalization and produced mixed results [11,14,15], ignoring revealing which kinds of international strategy is most effectively worked by a specific social capital. Moreover, researchers in organizational learning also acknowledge that social capital plays a vital role in firm's exploration and exploitation, but it fails to reveal the congruent relationship between specific social capital and exploration/exploitation [16,17]. Our research extends existing research by demonstrating the unique relationship between each external network and exploratory/exploitative internationalization.

Second, our findings can contribute to literature in international strategy. Although existing research has theoretically illustrated the concept and importance of carrying out both exploratory and exploitative strategies overseas $[8,9,51]$, few studies have empirically examined the innovation consequences of both strategies. Moreover, the extant literature on exploratory and exploitative internationalization also tends to overlook the interaction effects between organizational, strategic, environmental conditions and both strategies in explaining innovation performance. Our study contributes to this line of research by empirically demonstrating how and under what conditions exploratory and exploitative internationalization are more beneficial for innovation performance.

Third, our findings also contribute to literature about the relationship between internationalization and innovation in traditional international business literature. Most researchers argue that firms can obtain many resources and learning opportunities through entering into international markets [1], but empirical research on the relationship between internationalization and innovation achieve incompatible conclusions $[19,52,53]$. Our study advances the literature of this genre by providing empirical evidence to suggest that it is necessary to divide internationalization into exploratory and exploitative types and that the innovation effect of both international behaviors depends on their fit with organizational, strategic and environmental conditions. 
Our findings also have important practical implications. Our results suggest that external network is a good alternative support for international firms in emerging countries. Specifically, firms intending to explore in the international markets should establish and find support from their business and government network, which can provide them with enough resources and funds to burden the cost and risk of international exploration, while firms intending to exploit overseas should build and seek for support from their business and knowledge network, which can lay a solid foundation to meet foreign market demands. However, our results also inform that firms should notice the fit between international strategy selection and organizational, strategic, environmental factors, despite the positive innovation effect of exploratory and exploitative internationalization. In order to obtain greater innovation returns, firms with older age, entering into countries with low hosthome country similarity, or operating in dynamic foreign environment, should implement exploratory internationalization, whereas firms with younger age, entering into countries with high host-home country similarity, or operating in stable foreign environment, should carry out exploitative internationalization.

\subsection{Limitations and Future Research Directions}

Our research still has some limitations, which in turn offers opportunities for future research. First, the findings from this study with a cross-sectional research design are limited to the Chinese manufacturing context, and the sampled firms are from a few industries with different international degrees and innovation. Future research would be well served to extend the research from two points. Our theoretical model can be extended to a multi-industry and cross-country context. Because the sampled firms are largely from such top industries as electronic information and special equipment manufacturing, which may be much more connected to the international market and have dynamic research over other industries, we can increase the sample volume and conduct intra-industry comparative research among the original categorical industries, or between high and low technology industries. Conversely, we can carry out a longitudinal research design with case studies to explore the causal relationship among social capital, internationalization and innovation. Second, this study has paid attention to the effect of external network resources on exploratory and exploitative internationalization, ignoring focusing on the role played by internal resources. Therefore, future research can integrate resource-based views and social capital theory to test the comprehensive effect of both internal resources and external social capital on exploratory and exploitative internationalization. Third, we have examined the moderating effects of firm age, host-home country similarity and international environmental dynamism, and future research may examine the impact of other moderators at the organization, strategy and environment level. For example, such industry-level factors as industry competition and industry growth, and strategy-level factors as cost leadership vs. differentiation and incremental vs. radical innovation strategy, may be rewarding for future research. At last, whereas the present study intentionally focuses on the antecedent and innovation consequences of exploratory and exploitative internationalization, an alternative model can consider the ambidextrous effect of two international strategies. Further research should turn to consider the antecedent and innovation consequence of international ambidexterity, rather than focusing on the sole use of either exploration or exploitation.

Author Contributions: H.W. and Y.Q. conceived and designed the study. H.W. designed the questionnaire, collected the data, and conducted the data analysis. H.W. and Y.Q. wrote the manuscript. All authors have read and agreed to the published version of the manuscript.

Funding: This research was funded by National Natural Science Foundation, grant number 71972075, and the Humanities and Social Science Fund of Ministry of Education in China, grant number 19C10276025, and Science Research Program of The East China University of Political Science and Law, grant number 20HZK017.

Institutional Review Board Statement: Not applicable. 
Informed Consent Statement: Not applicable.

Data Availability Statement: The data that support the findings of this study are available from the authors upon reasonable request.

Conflicts of Interest: The authors declare no conflict of interest.

\section{References}

1. Wu, H.; Chen, J.; Jiao, H. Dynamic capabilities as a mediator linking international diversification and innovation performance of firms in an emerging economy. J. Bus. Res. 2016, 69, 2678-2686. [CrossRef]

2. Gawel, A. International trade in the high-tech sector-support or obstacle to start-up processes at the macro level in European Union countries? J. Theor. Appl. Electron. Commer. Res. 2021, 16, 1877-1892. [CrossRef]

3. March, J. Exploration and exploitation in organizational learning. Organ. Sci. 1991, 2, 71-87. [CrossRef]

4. Levinthal, D.A.; March, J.G. The myopia of learning. Strateg. Manag. J. 1993, 14, 95-113. [CrossRef]

5. Jansen, J.J.P.; Van Den Bosch, F.A.J.; Volberda, H.W. Exploratory innovation, exploitative innovation, and performance: Effects of organizational antecedents and environmental moderators. Manag. Sci. 2006, 52, 1661-1674. [CrossRef]

6. Duodu, B.; Rowlinson, S. The effect of social capital on exploratory and exploitative innovation: Modelling the mediating role of absorptive capability. Eur. J. Innov. Manag. 2019, 23, 649-674. [CrossRef]

7. Katila, R.; Ahuja, G. Something old, something new: A longitudinal study of search behavior and new product introduction. Acad. Manag. J. 2002, 45, 1183-1194. [CrossRef]

8. Makino, S.; Lau, C.-M.; Yeh, R.-S. Asset-exploitation versus asset-seeking: Implications for location choice of foreign direct investment from newly industrialized economies. J. Int. Bus. Stud. 2002, 33, 403-421. [CrossRef]

9. Wu, H.; Chen, J. International ambidexterity in firms' innovation of multinational enterprises from emerging economies: An investigation of TMT attributes. Balt. J. Manag. 2020, 15, 431-451. [CrossRef]

10. Bandeira-de-Mello, R.; Fleury, M.T.L.; Aveline, C.E.S.; Gama, M.A.B. Unpacking the ambidexterity implementation process in the internationalization of emerging market multinationals. J. Bus. Res. 2016, 69, 2005-2017. [CrossRef]

11. Hsu, C.-W.; Lien, Y.-C.; Chen, H. International ambidexterity and firm performance in small emerging economies. J. World Bus. 2013, 48, 58-67. [CrossRef]

12. Buckley, P.J.; Munjal, S.; Enderwick, P.; Forsans, N. Cross-border acquisitions by Indian multinationals: Asset exploitation or asset augmentation? Int. Bus. Rev. 2016, 25, 986-996. [CrossRef]

13. Patel, P.C.; Fernhaber, S.A.; Mcdougall-Covin, P.P.; Have, R.P.V.D. Beating competitors to international markets: The value of geographically balanced networks for innovation. Strateg. Manag. J. 2014, 35, 691-711. [CrossRef]

14. Pinho, J.C.; Prange, C. The effect of social networks and dynamic internationalization capabilities on international performance. J. World Bus. 2016, 51, 391-403. [CrossRef]

15. Acquaah, M. Social networking relationships, firm-specific managerial experience and firm performance in a transition economy: A comparative analysis of family owned and nonfamily firms. Strateg. Manag. J. 2012, 33, 1215-1228. [CrossRef]

16. Yavuz, R.I. Founders' education, social capital, and their interplay in new venture internationalization. J. Small Bus. Manag. 2021, 5, 1-37. [CrossRef]

17. Lu, Y.; Zhou, L.; Bruton, G.; Li, W. Capabilities as a mediator linking resources and the international performance of entrepreneurial firms in an emerging economy. J. Int. Bus. Stud. 2010, 41, 419-436. [CrossRef]

18. Yli-Renko, H.; Autio, E.; Sapienza, H.J. Social capital, knowledge acquisition, and knowledge exploitation in young technologybased firms. Strateg. Manag. J. 2001, 22, 587-613. [CrossRef]

19. Atuahene-Gima, K.; Murray, J.Y. Exploratory and exploitative learning in new product development: A social capital perspective on new technology ventures in China. J. Int. Mark. 2007, 15, 1-29. [CrossRef]

20. Martineaua, C.; Pastoriza, D. International involvement of established SMEs: A systematic review of antecedents, outcomes and moderators. Int. Bus. Rev. 2016, 25, 458-470. [CrossRef]

21. Mahmooda, I.P.; Zheng, W. Whether and how: Effects of international joint ventures on local innovation in an emerging economy. Res. Policy 2009, 38, 1489-1503. [CrossRef]

22. $\mathrm{Wu}, \mathrm{H}$.; Qu, Y. How do firms promote green innovation through international mergers and acquisitions: The moderating role of green image and green subsidy. Int. J. Environ. Res. Public Health 2021, 18, 7333. [CrossRef]

23. Hsu, C.; Lien, Y.; Chen, H. R\&D internationalization and innovation performance. Int. Bus. Rev. 2015, 24, 187-195. [CrossRef]

24. Dunning, J.H. International Production and the Multinational Enterprises; Allen and Unwin: London, UK, 1981.

25. Coleman, J.S. Social capital in the creation of human capital. Am. J. Sociol. 1988, 94, 95-120. [CrossRef]

26. Park, S.H.; Luo, Y.D. Guanxi and organizational dynamics: Organizational networking in Chinese firms. Strateg. Manag. J. 2001, 22, 455-477. [CrossRef]

27. Peng, M.; Luo, Y. Managerial ties and firm performance in a transition economy: The nature of a micro-macro link. Acad. Manag. J. 2000, 43, 486-501. [CrossRef]

28. Zhang, Y.; Li, H. Innovation search of new ventures in a technology cluster: The role of ties with service intermediaries. Strateg. Manag. J. 2010, 31, 88-109. [CrossRef] 
29. Cao, Q.; Gedajlovic, E.; Zhang, H. Unpacking organizational ambidexterity: Dimensions, contingencies and synergistic effects. Organ. Sci. 2009, 20, 781-796. [CrossRef]

30. Zhang, F.; Zhang, H.; Bell, G.G. Corporate religiosity and individual decision on conducting entrepreneurial activity: The contingent effects of institutional environments in China. Asia. Pac. J. Manag. 2021, 38, 955-978. [CrossRef]

31. Zheng, W.; Singh, K.; Mitchell, W. Buffering and enabling: The impact of interlocking political ties on firm survival and sales growth. Strateg. Manag. J. 2015, 36, 1615-1636. [CrossRef]

32. Guan, J.; Liu, N. Exploitative and exploratory innovations in knowledge network and collaboration network: A patent analysis in the technological field of nano-energy. Res. Policy 2016, 45, 97-112. [CrossRef]

33. Li, C.R.; Chu, C.P.; Lin, C.J. The contingent value of exploratory and exploitative learning for new product development performance. Ind. Mark. Manag. 2010, 39, 1186-1197. [CrossRef]

34. Mihalache, O.R.; Jansen, J.J.J.P.; Van Den Bosch, F.A.J.; Volberda, H.W. Offshoring and firm innovation: The moderating role of top management team attributes. Strateg. Manag. J. 2012, 33, 1480-1498. [CrossRef]

35. Scott, W.R. Organizations: Rational, Natural, and Open Systems, 3rd ed.; Prentice Hall: Hoboken, NJ, USA, 1992.

36. Farjoun, M.; Fiss, P.C. Thriving on contradiction: Toward a dialectical alternative to fit-based models in strategy (and beyond). Strateg. Manag. J. 2021. [CrossRef]

37. Sørensen, J.B.; Stuart, T.E. Aging, obsolescence and organizational innovation. Admin. Sci. Quart. 2000, 45, 81-112. [CrossRef]

38. Macpherson, A.; Holt, R. Knowledge, learning and small firm growth: A systematic review of the evidence. Res. Policy 2007, 36, 172-192. [CrossRef]

39. Levitt, B.; March, J.G. Organizational learning. Annu. Rev. Sociol. 1988, 14, 319-340. [CrossRef]

40. Vedel, J.B.; Kokshagina, O. How firms undertake organizational changes to shift to more-exploratory strategies: A process perspective. Res. Policy 2021, 50, 104118. [CrossRef]

41. Cui, L.; Meyer, K.E.; Hu, H.W. What drives firms' intent to seek strategic assets by foreign direct investment? A study of emerging economy firms. J. World Bus. 2014, 49, 488-501. [CrossRef]

42. Danneels, E. Organizational antecedents of second-order competences. Strateg. Manag. J. 2008, 29, 519-543. [CrossRef]

43. Lisboa, A.; Skarmeas, D.; Lages, C. Export market exploitation and exploration and performance: Linear, moderated, complementary and non-linear effects. Int. Mark. Rev. 2013, 30, 211-230. [CrossRef]

44. Dess, G.G.; Beard, D.W. Dimensions of organizational task environments. Admin. Sci. Quart. 1984, 29, 52-73. [CrossRef]

45. Luo, Y. Capability exploitation and building in a foreign market: Implications for multinational enterprises. Organ. Sci. 2002, 13, 48-63. [CrossRef]

46. Wu, H.; Chen, J.; Liu, Y. The impact of OFDI on firm innovation in an emerging country. Int. J. Technol. Manag. 2017, 74, 167-184. [CrossRef]

47. Chen, J.; Chen, Y.; Vanhaverbeke, W. The influence of scope, depth, and orientation of external technology sources on the innovative performance of Chinese firms. Technovation 2011, 31, 362-373. [CrossRef]

48. Jaworski, B.J.; Kohli, A.K. Market orientation: Antecedents and consequences. J. Mark. 1993, 57, 53-70. [CrossRef]

49. Xu, C.; Xiong, Y.; Sun, Y.; Liu, Y.P. Genetic distance, international experience and the performance of cross-border R\&D for EMNEs. J. Int. Manag. 2021, 27, 100853. [CrossRef]

50. Hoskisson, R.E.; Hitt, M.A.; Johnson, R.A.; Grossman, W. Conflicting voices: The effects of institutional ownership heterogeneity and internal governance on corporate innovation strategies. Acad. Manag. J. 2002, 45, 697-716. [CrossRef]

51. Arikan, I.; Koparan, I.; Arikan, A.M.; Shenkar, O. Dynamic capabilities and internationalization of authentic firms: Role of heritage assets, administrative heritage, and signature processes. J. Int. Bus. Stud. 2019, 10, 1-35. [CrossRef]

52. Sharma, P.; Yan, L.T. Differences in the impact of R\&D intensity and R\&D internationalization on firm performance- mediating role of innovation performance. J. Bus. Res. 2021, 131, 81-91. [CrossRef]

53. Si, Y.; Zhang, Y.; Teng, T. R\&D internationalization and innovation performance of Chinese enterprises: The mediating role of returnees and foreign professionals. Growth Chang. 2021, 9. [CrossRef] 